\title{
Menangkal Kepunahan Bahasa Tegalan
}

\author{
Fathurozi \\ Staf Balai Penelitian dan Pengembangan Agama Semarang
}

Kepunahan bahasa Ibu juga melanda Kota Tegal. Bahasa ini mulai ditinggalkan oleh generasi penerusnya. Mereka lebih enjoy mengunakan bahasa gaul. Lebih ironis, bahasa Indonesia dijadikan sebagai alat komunikasi antar anggota keluarga. Tak heran jika dialek lokal dari tahun-ketahun mulai tergusur.Menurut UNESCO, sekitar 140 bahasa daerah terancam kepunahan.

Lebih memprihatinkan lagi orang-orang yang merantau ke ibukota, ketika pulang ke tanah kelahirannya menularkan bahasa baru. Bahkan mereka enggan mengunakan bahasa nenek moyangnya, mungkin mereka malu karena bahasa Tegal sebagai bahan lawakan oleh artis-artis komedian.

Kelihatannya bahasa Indonesia ikut andil dalam kepunahan bahasa lokal. Semisal guru lebih suka berkomunkasi dengan muridnya memakai bahasa nasional daripada dialek asalnya. Tak ayal siswa sering mengunakan bahasalndonesia untuk berkomunikasi dengan teman-teman sepermainannya. Bahkan orang tua lebih memilih mengajarkan bahasa Indonesia daripada bahasa lokal.

Padahal Undang-undang 45, Bab XIII Pasal 32 Ayat 2 menyebutkan bahwa "negara menghormati dan memelihara bahasa daerah sebagai kekayaan budaya nasional." Hal ini mewajibkan tiap warga negara untuk melestarikan bahasa daerahnya.

Menurut Dorian (1978) dalam Sumarsono dan Partana, (2008) bahasa yang punah itu tidak tahan terhadap persaingan bahasa yang lain bukan karena persaingan prestise antar ragam bahasa dalam satu bahasa. Melihat semua ini budayawan di Tegal mencoba melestarikan bahasa ngapak-ngapak dengan berbagai cara semisal membuat lomba penulisan puisi mengunakan bahasa Tegalan.

Tahun 1994, peyair Lanang Setiawan mengalih bahasakan puisi W.S Rendra "Nyanyian Angsa" menjadi "Tembangan Banyak". Kemudian jejaknya diikuti sastrawan-sastrawan Tegal yakni Rofie Dimyati menerjemahkan "Rick dari Corona" menjadi "Rick Sing Corona", Nurhidayat Poso menerjemahkan "Laki-Laki dan Perempuan (F. Rahardi)," menjadi "Wong Wadon Karo Wong Lanang", juga puisi Emha Ainun Nadjib "Lima Menit Saja”, menjadi “Lima Menit Bae", oleh M. Enthieh Mudakir dan sebagainya. 


\section{Nilai-nilai Sosial}

Menurut Kloss (1984) terdapat tiga penyebab kepunahan bahasa. Pertama, guyup tuturnya lenyap seperti terjadinya bencana alam yang melenyapkan suatu komunitas pemakai bahasa dan lain-lain. Kedua bahasa itu menyerah kepada "pertentangan intrinsik prasarana budaya modern yang berdasarkan teknologi”. Ketiga, Kepunahan bahasa nominal melalui metamorfosis.

Kondisi ini, menjadikan bahasa lokal sulit berkembang dan malah makin terpinggirkan, dan kehilangan maknanya. Padahal bahasa Tegalan memiliki nilai-nilai sosial bisa dijadikan modal kerukunan.Ungkapan bahasa Tegalyang mengandung nilai sosial, penuh kearifansekaligus sebagai seperangkat pengetahuan kehidupan sosial.

Wilayah yang terkenal dengan sebutan "Jepangnya Indonesia" terdapat ungkapanungkapan yang mengandung nilai sosial yakni.Pertama "Laka Musuh Bala Kabeh" yang artinya "Kita tidak punya musuh, semua sahabat.

Kedua, "sambatan" artinya mengerjakan segala sesuatu dengan sama-sama.Kondangan adalah media pertemuan keluarga kerabat dan tamu undangan dalam merayakan rasa syukur atau ungkapan kegembiraan atas tercapaianya sesuatu yang diharapkan seperti acara pernikahan, khitanan tetapi sifatnya gentenan.

Kemudian Sinoman adalah sebutan bagi orang-orang yang menjadi juru laden atau orangorang yang melayani para tamu manakala ada hajatan (acara besar seperti pernikahan atau khitanan) yang tengah dilakukan oleh tetangga.

Terakhir "pemali" (Jangan duduk di tengah pintu nanti susah mendapat jodoh. Jangan makan sambil berdiri nanti rejekinya jauh). Namun ungkpan-ungkapan bahasa ngapak ini cenderung dilupakan. Padahal jika mau menggali maknanya akan menimbulkan kerukunan antar masyarkat dan terhindar dari sikap saling curiga-mencurigai.

Untuk menangkal kepunahan bahasa Tegalan, kiranya perlu mengumpulkan semua kosakata yang tersebar dimasyarakat, lalu diklasifikasi mana yang termasuk ucapan positif dan negatif. Kemudian dipindahkan dari teks buku ke dalam bentuk teks gital atau ke dalam CD, hal ini akan memacu semangat minat baca masyarat Tegal dan jika memungkinkan membuat Web yang membahas seputar bahasa ngapak dan membuka forum diskusi yang memungkinkan orang asal Tegal yang menetap di luar kota bisa ikut memelihara bahasanya.

Dimuat Koran Tribun Jateng, Sabtu 19 Maret 2016

http://jateng.tribunnews.com/2016/03/19/menangkal-kepunahan-bahasa-tegalan 